\title{
An examination of accounting internship on subsequent academic performance
}

\author{
P. M. C. Thilakerathne, M. W. Madurapperuma \\ Department of Accountancy, Faculty of Commerce and Management Studies, University of Kelaniya, Sri Lanka
}

Email address:

lal@kln.ac.lk (P. M. C. Thilakerathne), wasanthi@kln.ac.lk (M. W. Madurappruma)

\section{To cite this article:}

P. M. C. Thilakerathne, M. W. Madurapperuma. An examination of Accounting Internship on Subsequent Academic Performance. International Journal of Economics, Finance and Management Sciences. Vol. 2, No. 1, 2014, pp. 8-15.

doi: $10.11648 /$ j.ijefm.20140201.12

\begin{abstract}
Increasingly, internship has become an essential component of the undergraduate degree programmes. It provides students with a smooth transition from on-campus environment to the working environment. It is often viewed as a 'win-win' situation for both the intern and the intern's employers. Students are able to learn about the profession and gain practical experience while simultaneously being able to reflect on what they have learned in the classroom. Employers benefit from internships because interns are sources of future employees. The relationship between Internship and academic performance on accounting degree is significantly under-researched. This paper examines the effect of accounting student internships on subsequent academic performance in one of the national universities in Sri Lanka. For this purpose post-internship course unit performance of students with accounting internship experience were considered. Readily available data on internship status, gender and prior achievement of accounting special degree undergraduates were used. Linear regression models were constructed using the data with undergraduates. Research finds that internships do a have a positive impact on learning and higher scores tend to have a higher GPA and gender is negatively correlated with GPA signaling that male students performed better than female students.
\end{abstract}

Keywords: Academic Performance, Accounting Students, Internship Program, Gender, Work-Based Learning, Grade Point Average

\section{Introduction}

Universities and alternate higher educational institutions in Sri Lanka offer internships for their undergraduate students to provide a smooth transition from the academic world to the working environment. Modern internships can be traced back to 1906 when the University of Cincinnati started its internship program (Weible, 2010)). Internships are now a requirement for licensure toward professional certification in Sri Lanka. Undergraduate education programs in Accounting, Finance, Marketing, Human Resource Management, Medicine, Engineering, Nursing, and other Social Science programmes all embedded internships. These required work experiences are more popular with professional degree like accounting.

Internships provide many advantages to students ranging from gaining experience and obtaining career-related direction to networking (Cook, R., Parker, \& Pettijohn, 2004) (Lam \& Ching, 2006), (Gault, Redington, \& Schlager T, 2000). Researchers (Clark, 2003), (Hymon-Parker, 1998),
(Weible, 2010), find that advantages of internships for students are increased career opportunities, higher salaries, quicker job offers, faster promotion rates, job satisfaction, ease of transition from university to work, better communication skills, working, and applying the knowledge gained from the classroom.

Internships provide advantages for universities as well. By offering internship opportunities, the institution builds a linkage relationship with businesses that may eventually hire their graduates. These linkage relationships also provide feedback to the institution on the application of the student's curriculum in the university and thus help in keeping curriculum according to the industry expectations.

Subsequently, there is a considerable body of research in the literature investigating benefit of the Internship programme (Gault et al., 2000) (Schambach \& Dirks, 2002). The present study was intended to explore to what extent, if any, participating in an internship experience has an impact on student Grade Point Average (GPA). Although some of the existing research focuses on academic performance and 
internship in management courses, there is very little research in Sri Lanka and a paucity of research into the relationship between Accounting Internship and academic performance. This study aims to examine some of the factors influencing academic performance in an accounting degree.

This paper is organized as follows; the next section provides the review of existing literature on internship, section 3 deals with variables identified for the study and hypothesis development, section 4 presents the methodology adopted in this study. section 5 describes the further analyses and discussion and section 6 report the findings, conclusion, and areas for further research.

\section{Literature Review}

On-the-job learning and training dates back to as early as $600 \mathrm{BCE}$, however modern internship programs in higher education can be traced back to 1906 and the University of Cincinnati. Recent data indicate that most of the business schools offer internship programs for their students, and research has indicated the benefits for students, universities, and businesses involved in internships.

Students who participate in internships benefit by increased marketability (Divine, Linrud, Miller , \& Wilson 2007); (Swift, 1999) and higher salaries (Coco, 2000), (Gault et al., 2000). (Furco, 1996) defines internship as engaging students in service activities primarily for the purpose of providing them with hands-on experience that enhances their learning or understanding of issues relevant to a particular area of study. According to (Lam \& Ching, 2006) internship can assist students to bridge the gap between the academic learning process and the practical reality. (Cook et al., 2004) found that students believed their internship helped them to work with a variety of people in different work environments. The experience enabled them to get along with others, to become mature, and to relate theories learned in the classroom to work. These same students had increased confidence in obtaining a job after graduation and, internships had influenced their career choices. Money was not the primary reason students chose an internship; the largest perceived benefits to internships were the development of social skills and enhanced personal maturity, and they found that their internship program was valuable (Cook et al., 2004).

Prior research (Divine et al., 2007) an internship's benefits to a student are: work experience that strengthens their resume, a better understanding of the working world, and a better foundation for making adjustments from the academic world to the work environment. The opportunity allows students to see the application of college learning and theories, bringing real world experiences back to the classroom and sharing with others about their internship activities. Interns can improve their job-related skills, increase leadership skills, and clarify their career goals. They are then better prepared for a job after graduation, which increases their marketability compared to students lacking internships.
The internship programme contributes significantly and positively towards enhancing the knowledge base and motivational level of students (Beard, 1998). According to her, this experience can make subsequent study more meaningful and is useful to develop students professionally before entering the workplace.

The rationale in offering the internship attachment as part of the academic programme is that students benefit from these internship experiences and exposure. According to (Cannon \& Arnold, 1998), internship may pave the way for permanent employment upon graduation as well as providing an in-depth understanding of actual business practice. Further, business graduates with internship experience are likely to get conspicuously higher starting pay and report greater job satisfaction compared to their non-internship counterparts (Gault et al., 2000). Internship offers the formal work experience - which is often highly valued by employers (Little \& Harvey, 2006). In the Sri Lanka this is offered by some HE institutions in the form of a one-year Internship with a single employer as part of a planned programme of study (alternative forms of Internship include two six month stints at different employers or much shorter periods such as six weeks or three months). The Internship normally occurs between the third and final years of study, is supervised and the student is required to produce an assessed report relating to the Internship experience. Whilst such Internships may potentially increase a students' employability because employers value the work experience itself, it is also of interest to see whether Internship improves students' academic performance in the year following Internship.

There is, however, little evidence that work Internship enhances academic development. As (Little \& Harvey, 2006) point out:

Very little research explicitly explores how the Internship experience translates into academic development from the point of view of current students. Much is taken for granted, the observed maturity of undergraduates returning from a period of work Internship is assumed to carry over into a more studious or reflective approach to learning but there is little direct evidence to be found of this in the literature.

There is almost few research (English \& Koeppen, 1993), (Knechel \& Snowball, 1987) into the relationship of Internship to academic performance in an accounting and auditing context. (Gracia \& Jenkins, 2003) considered the relationship of Internship to final year performance but as internship did not appear in their final stepwise regression model, the relationship was unquantified.

(Duignan, 2002) found no significant difference between the performance (using mean module percentage scores) of Internship and full-time business undergraduates. He suggested that this did not mean that students had failed to learn on Internship but it was 'suggestive of a failure to exploit to the full the learning potential of the Internship with respect to those attributes that are commonly valued and evaluated by academics'. (Duignan, 2003) also argues that 'the skills and competencies that are engendered by 
successful Internships are not easily transferable into academic performance'.

More research studies have been published on Internship in non-accounting contexts. (Gomez, Lush, \& Clements, 2004b) analysed graduate students on a bioscience degree over a two year period. The effect of type of course followed and gender, amongst other factors, on aggregate percentage marks in each of the three years on the course were examined. They found no significant difference in performance between males and females in the first two years but that female performed significantly better than males in the final year. In contrast to this (Duignan, 2002), those taking the optional Internship course performed significantly better than those following the normal, full-time degree in the final year. In addition, there was no significant difference between the performance of male and female Internship students in the final year following the year of Internship.

(Rawlings, White, \& Stephens, 2005) examined students graduating from information systems degrees over a four year period. They found that the probability of gaining a first or higher second degree classification was greater for students on Internship rather than full-time courses (for students scoring at least $50 \%$ in their second level exams). They also found that there was a significant interaction between second-year marks and Internship status on degree classification. (Mandilaras, 2004) also found that Internship students in an economics degree had a significantly better chance of achieving a higher degree (first and upper second).

Students on a human psychology degree over a six year period were studied by (Reddy \& Moores, 2006). Internship students significantly improved their final-year marks (compared to second-year marks) by 3.2\% compared with $1.5 \%$ for those students not going on Internship and they hypothesised that $14 \%$ of students improved their degree class by undertaking a Internship. However, they noted that Internship students had higher second-year grades and might have been expected to improve more in the final year. Furthermore, Research has shown mixed results as to whether an internship improves student performance as measured by GPA. Thus, the relationship between Internship in Accounting and academic performance is thus worthy of further study.

\section{Variable Identification and Hypothesis Development}

There have been many studies which have examined the factors influencing performance on undergraduate accounting and finance courses. Studies by, (Lane \& Porch, 2002), (Duff, 2004), (Gammie, Jones, \& Robertson-Millar, 2003), (Turner, Holmes, \& Wiggins, 1997), (Wooten, 1998), (Jackling \& Anderson, 1998), (Bartlett, Peel, \& Pendlebury, 1993b), and (Koh \& Koh, 1999) all report the statistical significance of prior achievement on university performance. Generally it is the most recent prior performance which is of significance with (Gammie et al., 2003) concluding 'performance in the early years of the degree programme appears to supersede school performance'. Most often general measures of prior performance are used e.g. previous year average marks at university or points scores based on school qualifications but more specific measures such as performance in particular subjects/modules at university or school have been employed in some studies (Gammie et al., 2003) and (Bartlett et al., 1993b).

A number of studies have considered the effect of gender on accounting performance. (Gracia \& Jenkins, 2003) found that females significantly outperformed males in the second year, but the effect disappeared in the final year. (Koh \& Koh, 1999) reported that males outperformed females in the first two years of the course but that there was no significant difference in the third year. (Gammie et al., 2003), (Turner et al., 1997), (Jackling \& Anderson, 1998), (Carpenter \& Friar, 1993) found no significant gender difference. Whilst there was no evidence that females significantly outperformed males, (Lipe, 1989), did find a significant interaction between the gender of the student. In non-accounting contexts the findings are again mixed with (Morrison, Merrick, Higgs, \& Le Metais, 2005), (Woodfield, Jessop, \& McMillan, 2006) and (Gomez, Lush, \& Clements, 2004a) finding that females performed significantly better than males but (Jochems, Snippe, Smid, \& Verweij, 1996) and (De Vita, 2002) finding no significant difference.

From the literature reviewed above the following key issues were identified.

- The relationship of Internship to academic performance on accounting and finance degrees is significantly under-researched.

- $\quad$ Prior academic achievement, measured in a variety of ways, is significant in many studies. Typically the most recent prior achievement is significant. (However, it may be that this prior academic achievement is simply a proxy for something else e.g. a particular learning approach or kind of motivation or level of intelligence and that the most recent prior achievement is simply the current manifestation of this something else).

- There are interesting, but no consistent, findings on the effect of gender.

- $\quad$ There is no common way of measuring performance and this makes comparisons between studies very difficult. For example, performance can be measured using average marks, grades, degree classifications etc.

- $\quad$ Studies vary in the level examined i.e. first, second or final years, with an examination of first-year performance being the most common (which may in part explain the lack of research into Internship which occurs later in degree courses).

Therefore, this research aims to address these key issues by examining the effect of Internship training, prior academic achievement and gender on final year performance using average marks. 


\section{Research Methodology}

This study sought to determine if an internship experience had any significant impact to improve GPA for students enrolled in an Accounting degree program of the University of Kelaniya, Sri Lanka. The methodology used was a deductive form of logic wherein theories and hypotheses are tested in a cause-and-effect order. Concepts, variables, and hypotheses were chosen before the study began and remained fixed throughout the study. The intent of the study was to develop generalizations that would contribute to the theory and enable one to better predict, explain, and understand the phenomenon (Creswell, 1994).

The university maintains computerised student records containing a range of information including gender, previous academic records, and type of course followed. The final-year average percentage mark, were used as the dependent variables in the regression models.

\subsection{Model Specification}

\section{GPAY $4=\mathrm{C}_{(1)}+\mathrm{C}_{(2)}($ GENDER $)+\mathrm{C}_{(3)}($ ZSCORE $)+$ $\mathrm{C}_{(4)}($ INTERNMARKS $)+\mathrm{C}_{(5)}($ GPAY3)}

The independent variables chosen for study based on the key issues identified in the literature review and the readily available data were as follows.

- $\quad$ Gender $-\mathbf{C}_{(2)}-($ male $=0$, female $=1)$ which features in much of the other research in this area. Anecdotally, staff teaching students in the final year of the degree course feel that female Internship students perform best of all. The inclusion of a gender variable (and the interaction variable below) will allow this to be assessed and directly compared with the findings of previous studies.

- $\quad \mathrm{C}_{(3)}$ - Z-Score ('A' level points) as a measure of prior school-level achievement. Intuitively, prior academic attainment might be expected to influence performance i.e. those with higher Z-Score might be expected to perform better than those with lower scores.

- $\mathbf{C}_{(4)}$ - Internship marks of fourth year Internship course unit

- C (5) - Third-year average marks. Prior research indicates that the most recent academic performance is normally significant

The university's Senate approved the data were used for the study and no students were to be individually identified.

Quantitative research study was used correlations for the analysis of the degree of the relationship between the dependent variable of student internship and the pattern of behaviour seen GPA (Gall, Borg, \& Gall, 1996). This was an observational, retrospective study examining data from students who enrolled in accountancy degree in 2010/12. All were students who declared accountancy major upon entrance or graduated with an accountancy degree. The sample comprised students sat for their final-year exams in academic session of 2011/2012. (“All Students"). The University of kelaniya, Sri Lanka currently has annual enrollments of approximately 100 students.

The data was analysed using linear regression in SPSS 18.0. Further analysis was undertaken where possible using t-tests of significance to compare means. In judging levels of significance, standard levels $(1 \%, 5 \%$ and $10 \%)$ are used throughout.

To better understand the benefits that internships have on students' performance, it is necessary to ascertain what impact student internships have on GPA. The hypothesis tested in this study is that there exists a relationship between internships and GPA, The expected results for the research question were that internships are able to contribute to a student's overall success and learning, as demonstrated through a higher GPA. The null hypothesis $\left(\mathrm{H}_{0}\right)$ is that there is no relationship between internships and GPA; that any detected differences are due strictly to chance. The alternative hypothesis $\left(\mathrm{H}_{1}\right)$ states that there is a relationship between internships, and GPA;

The expected results for the research question were vetted through the following research questions:

1. Does participation in a student internship impact overall, final GPA?

2. Does participation in a student internship significantly improve GPA for the Year following an internship compared to prior year?

3. Does prior academic achievement influence current performance?

4. Is there a significant difference in the performance of males and females?

This study sought to answer the above research questions:

Multiple regressions were carried out. Checks were made for multicollinearity and the residuals were examined for normality and no problems were found. Accordingly, there is nothing to cast doubt on the appropriateness of the modelling approach.

A total of 100 students were involved in the internship attachment for the academic year of 2010/2011. However, 82 students were considered because 12 have not completed the degree. A demographic profile (See Table 1) for the interns is captured and the majority of the interns are females $(53.7 \%)$. For this purpose cross-sectional analysis was performed to assess the relationship of student internship across the sample, as a whole.

\section{Question 1: Does Participation in an Internship Improve Overall, Final GPA?}

The results are statistically significant, and the research hypothesis is supported by the data. Internships do have a positive impact on learning, as measured by improved final GPAs. 
Table 1. Descriptive statistics, correlations and results from the regression analysis

\begin{tabular}{llll}
\hline Variable & Mean & $\begin{array}{l}\text { Standard } \\
\text { Deviation }\end{array}$ & $\begin{array}{l}\text { Correlation with } \\
\text { Graduate GPA }\end{array}$ \\
\hline $\begin{array}{l}\text { Gender } \\
\text { Male }\end{array}$ & & \\
Female & $46.3 \%$ & & -.150 \\
Z-score & $53.7 \%$ & & \\
Pre-Performance & 3.0596 & .42170 & $.791\left(^{* *}\right)$ \\
InternMarks & 66.3049 & 8.72868 & $.694(* *)$ \\
\hline
\end{tabular}

Correlation and multiple regression analysis were conducted to examine the relationship between Graduate performance and various predictors. As can be seen each of the predictor variables are positively and significantly correlated with the criterion, indicating that those with higher scores on these variables tend to have higher GPA. Gender is negatively correlated with Graduate GPA (Coded as 1-Male and 2-female) indicating that male student have higher GPA.

Multiple regression analyses were subsequently performed and the results are shown in table 2 .

Table 2 shows that the multiple regression model with all four predictors produced $\mathrm{R}^{2}=0.71, \mathrm{~F}(4,77)=47.92, \mathrm{p}<$ 0.01 ) as can be seen in model summary and ANOVA TABLES. The Z-score is not statistically significant. Table 2 shows third-year average GPA is a significant predictor for final-year marks and not in gender. Internship marks is now significant $(p<0.05)$, with Internship adding around 3\% and $2.3 \%$ to the average final -year mark of All Students. The model is significant in each case $(\mathrm{p}<0.01)$.

\section{Question 2: Does Participation in an Internship Significantly Improve GPA for the year following an Internship Compared to Prior year?}

Table 3 reflects the outcome of the t-test (two samples for means) performed to compare the differences between matched pairs for improved average GPA between post- and pre internship year. This $t$ test for matched pairs was conducted to measure effect of internship towards GPA achievement. The t-test produced a p-value of 0.0129 , meaning the probability that the improvement of the year GPA by chance is less than $1 \%$. With a p-value less than .05 , there is enough evidence to reject the null hypothesis; results are statistically significant and the research hypothesis is supported by the data. Therefore, internships have a positive impact on learning, as measured by improved, year GPA averages.

\section{Question 3: Is there a significant difference in the performance of males and females between Post- and Pre-Internship year?}

Difference in the performance of males and females in pre and post internship situation tested by using Mann-Whitney $\mathrm{U}$ and Wilcoxn $\mathrm{W}$ tests and show that the two-sided p-values from both asymptotic 2-tailed and exact 2-tailed are 0.000 (see Table $4 \& 5$ ). For one-sided test, mean ranks of male is less than mean rank from female. This suggests the median from female is higher than median for male. The p-value would be half of the p-value from two-tailed test and would be 0.001 in supporting that the median GPA in $3^{\text {rd }}$ year for female is higher than the median GPA in $3^{\text {rd }}$ year for male. Female students showed a greater increase in GPA post-internship than did male students. However, there were no significant differences that females performed better than males in final years.

\section{Further Analyses and Discussion}

Intuitively, prior academic attainment (measured as ' $\mathrm{A}$ ' level Z-scores) might be expected to influence performance i.e. those with higher Z-scores might be expected to perform better than those with lower scores. This study shows that prior achievement has no significant effect for the Graduates in the final year. In (Woodfield et al., 2006), 'A' level $\mathrm{Z}$-score points were only a significant predictor of final-year performance for females.

Other studies (Gomez et al., 2004b) and (Gracia \& Jenkins, 2003) have found that previous years marks are a significant determinant of final-year performance as was the case in this study i.e. most recent prior achievement (rather than older prior achievement) is significant. This study only found it was shown to be a significant independent determinant of performance. Students who go on Internship achieve significantly better final-year marks. Final-year marks have a $75 \%$ weighting when determining degree class, hence Internship can have a major impact making the difference between a first and upper second, and lower second. Internship attachments are also found to successfully enhance students' performance in accounting and auditing courses as well as in their overall GPA performance (English \& Koeppen, 1993); (Knechel \& Snowball, 1987)).This research supports that finding of (English \& Koeppen, 1993); (Knechel \& Snowball, 1987) albeit in terms of an interaction between third-year average marks and internship status on final-year marks (rather than degree class).

\section{Conclusions, Limitations and Further Research}

This paper goes some way to overcoming the paucity of research into the relationship of Internship to academic performance on accounting degrees. A statistically-significant better performance of internship students, as measured by average marks, has been found. Better average marks may in turn result in a higher class of degree and, anecdotally where employers require good degrees (first or upper second), better employment prospects.

This study has been confined to a single degree course within a single institution so it cannot be assumed that the results can be generalised to other courses within the same institution or to other institutions. Amongst other things, 
there may be differences between course work and examination weightings, the nature of the assessment undertaken. Additionally, multiple linear regression models are used which in itself assumes the relationship between the variables is linear, which of course, it may not be. The $\mathrm{Z}$ score was used as a measure of pre-university achievement as the data were readily available. However, the $\mathrm{Z}$ score may be a proxy for some other variable such as IQ, which could have been used instead. Importantly, no causal relationship has been shown i.e. that Internship causes an improvement in academic performance.

Table 2

\begin{tabular}{|c|c|c|c|c|}
\hline \multicolumn{5}{|c|}{ Dependent Variable: GPAY4 } \\
\hline \multicolumn{5}{|c|}{ Method: Least Squares } \\
\hline \multicolumn{5}{|c|}{ Sample (adjusted): 182} \\
\hline \multicolumn{5}{|c|}{ Included observations: 82 after adjustments } \\
\hline Variable & $\begin{array}{l}\text { Coeffici } \\
\text { ent }\end{array}$ & Std. Error & t-Statistic & Prob. \\
\hline $\mathrm{C}$ & $\begin{array}{l}-0.08717 \\
7\end{array}$ & 0.892878 & -0.097635 & 0.9225 \\
\hline GENDER & $\begin{array}{l}0.07959 \\
7\end{array}$ & 0.057122 & 1.393463 & 0.1675 \\
\hline ZSCORE & $\begin{array}{l}0.00510 \\
1\end{array}$ & 0.465603 & 0.010956 & 0.9913 \\
\hline INTERNMARKS & $\begin{array}{l}0.01557 \\
2\end{array}$ & 0.003787 & 4.112015 & 0.0001 \\
\hline GPAY3 & $\begin{array}{l}0.63469 \\
5\end{array}$ & 0.084210 & 7.537038 & 0.0000 \\
\hline R-squared & $\begin{array}{l}0.71341 \\
8\end{array}$ & \multicolumn{2}{|c|}{ Mean dependent var } & $\begin{array}{l}2.9335 \\
37\end{array}$ \\
\hline Adjusted R-squared & $\begin{array}{l}0.69853 \\
0\end{array}$ & \multicolumn{2}{|c|}{ S.D. dependent var } & $\begin{array}{l}0.4204 \\
01\end{array}$ \\
\hline S.E. of regression & $\begin{array}{l}0.23082 \\
6\end{array}$ & \multicolumn{2}{|c|}{ Akaike info criterion } & $\begin{array}{l}-0.0352 \\
65\end{array}$ \\
\hline Sum squared resid & $\begin{array}{l}4.10262 \\
0\end{array}$ & \multicolumn{2}{|c|}{ Schwarz criterion } & $\begin{array}{l}0.11148 \\
6\end{array}$ \\
\hline Log likelihood & $\begin{array}{l}6.44586 \\
8\end{array}$ & \multicolumn{2}{|c|}{ Hannan-Quinn criter. } & $\begin{array}{l}0.0236 \\
53\end{array}$ \\
\hline F-statistic & $\begin{array}{l}47.9209 \\
1\end{array}$ & \multicolumn{2}{|c|}{ Durbin-Watson stat } & $\begin{array}{l}2.0909 \\
11\end{array}$ \\
\hline Prob(F-statistic) & $\begin{array}{l}0.00000 \\
0\end{array}$ & & & \\
\hline
\end{tabular}

(Bartlett, Peel, \& Pendlebury, 1993a) concluded that performance cannot be entirely explained by background variables such as gender and prior performance. Other factors such as motivation, personality and attitude are likely to be as important. What this study shows is that Internship provides a good focus for considering these other factors and requires further research. There may be personality/motivation/attitude factors that predispose a student to undertake an Internship (e.g. improved employment prospects from having work experience and a better degree drive better performance) or not (e.g. those who switch to a full-time from a Internship course) and these might be why Internship students perform better rather than anything to do with the Internship itself. On the other hand, Internship might equip students with skills which are useful in the final-year and which improve their performance i.e. the Internship itself does have a beneficial impact. With the findings that an internship does have a positive impact on GPA, a qualitative study should be conducted to learn students' perspectives on the added value from having an internship. Further research should focus on students who have completed internship and should be interviewed to see what effect, if any, the internship had on motivation to complete a degree, performance in the classroom, and career decisions. Qualitative research should be conducted through semi structured interviews with students who have completed internships.

Table 3. T-Test for Matched Pairs' Difference in GPA between Post- and Pre-Internship years

\begin{tabular}{lll}
\hline & 3-Year GPA & Final year GPA \\
\hline Mean & 3.059634146 & 2.932317 \\
Variance & 0.177828803 & 0.369534 \\
Observations & 82 & 82 \\
Pearson Correlation & 0.564188385 & \\
Hypothesized Mean Difference & 0 & \\
df & 81 & \\
t Stat & 2.269309956 & \\
P(T<=t) one-tail & 0.012954198 & \\
t Critical one-tail & 1.663883913 & \\
P(T<=t) two-tail & 0.025908396 & \\
t Critical two-tail & 1.989686323 & \\
\hline
\end{tabular}

In addition to above paired sample test found that GPA increased significantly from third year to $4^{\text {th }}$ year, indicating the values for $\mathrm{t}(81)=$ 4.19 , p-value $=0.000)$.

Table 4. Ranks

\begin{tabular}{lllll}
\hline & sex & N & Mean Rank & Sum of Ranks \\
\hline \multirow{2}{*}{ GPAY3 } & female & 44 & 48.99 & 2155.50 \\
& Male & 38 & 32.83 & 1247.50 \\
& Total & 82 & & \\
\hline
\end{tabular}

Table 5

\begin{tabular}{ll}
\hline & GPAY3 \\
\hline Mann-Whitney U & 506.500 \\
Wilcoxon W & 1247.500 \\
Z & -3.064 \\
Asymp. Sig. (2-tailed) & .002 \\
Exact Sig. (2-tailed) & .002 \\
Exact Sig. (1-tailed) & .001 \\
Point Probability & .000 \\
\hline
\end{tabular}

\section{References}

[1] Bartlett, S., Peel, M. J., \& Pendlebury, M. (1993a). From fresher to finalist: a three year analysis of student performance on an accounting degree programme. Education, 2(2), 111-122. 
[2] Bartlett, S., Peel, M. J., \& Pendlebury, M. (1993b). From fresher to finalist: a three year analysis of student performance on an accounting degree programme. Accounting Education, 2(2), 111-122.

[3] Beard, D. F. (1998). Beard, D.F., (1998). The status of internship / cooperative education experiences in accounting education. Journal of Accounting Education, 16, 507-516. Journal of Accounting Education, 16, 207-516.

[4] Cannon, J. A., \& Arnold, M. J. (1998). Student expectations of collegiate internship programs in business: A 10-year update. Journal of Education for Business, 73, 202-205.

[5] Carpenter, V. L., \& Friar, S. (1993). Evidence on the performance of accounting students:race, gender, and expectations. Issues in Accounting Education, 8(1), 1-17.

[6] Clark, S. (2003). Enhancing the educational value of business internships. Journal of Management Education, 27(4), 472-484.

[7] Coco, M. (2000). Internships: A try before you buy arrangement. Advanced Management Journal 65(2), 41-43.

[8] Cook, S. J., R., S., Parker, \& Pettijohn, C. E. (2004). The perceptions of interns: A longitudinal case study. Journal of Education for Business(79), 179-185.

[9] Creswell, J. W. (1994). Research design: Qualitative and quantitative approaches.

[10] De Vita, G. (2002). Cultural equivalence in the assessment of home and international business management students: a SL exploratory study. Studies in Higher Education, 27(2), 221-231.

[11] Divine, R., Linrud, J., \, Miller, R., \& Wilson , J. H. (2007). Required internship programs in marketing: Benefits, challenges and determinants of fit. Marketing Education Review, 17(2), 45-52.

[12] Duff, A. (2004). Understanding academic performance and progression of first-year accounting and business economics undergraduates: the role of approaches to learning and prior academic achievement. Accounting Education, 13(4), $109-430$.

[13] Duignan, J. (2002). Undergraduate work Internship and academic performance: failing by doing, Conference Proceedings HERDSA Quality Conversations International Conference. Edith Cowan University, Perth, Western Australia.

[14] Duignan, J. (2003). Internship and adding value to the academic performance of undergraduates: reconfiguring the architecture - an empirical investigation. Journal of Vocational Education, 55(3), 335-350.

[15] English, D. M., \& Koeppen, D. R. (1993). The relationship of accounting internship and subsequent academic performance. Issues in Accounting Education, 292-299.

[16] Furco, A. (1996). Service Learning and School-to-Work. Journal of Cooperative Education, 1, 7-14.

[17] Gall, M., Borg, W., \& Gall, J. (1996). Educational research: An introduction: White Plains, NY: Longman.

[18] Gammie, E., Jones, P. L., \& Robertson-Millar, C. (2003). Accountancy undergraduate performance: a statistical model,. Accounting Education, 12(1), 63-78.
[19] Gault, J., Redington, J., \& Schlager T. (2000). Undergraduate business internships and career success: Are they related? Journal of Marketing Education, 22, 45-53.

[20] Gomez, S., Lush, D., \& Clements, M. (2004a). Work Internships enhance the academic performance of bioscience undergraduates. Journal of Vocational Education and Training, 56(3), 373-383.

[21] Gomez, S., Lush, D., \& Clements, M. (2004b). Work Internships enhance the academic performance of bioscience undergraduates. Journal of Vocational Education and Training, 56(3), 373-386.

[22] Gracia, L., \& Jenkins, E. (2003). A quantitative exploration of student performance on an undergraduate accounting programme of study. Accounting Education, 12(1), 15-32.

[23] Hymon-Parker, S. (1998). Benefits and limitations of internships as viewed by educators and retailers/commentary. Journal of Family and Consumer Sciences (90), 76-81.

[24] Jackling, B., \& Anderson, A. (1998). Study mode, general ability and performance in accounting: a research note. Accounting Education, 7(1), 65-73.

[25] Jochems, W., Snippe, J., Smid, H. J., \& Verweij. (1996). The academic progress of foreign students: study achievement and study behaviour. Higher Education, 31(3), 325-340.

[26] Knechel, W. R., \& Snowball, D. (1987). Accounting internship and subsequent academic performance: An empirical study. The Accounting Review, 799-807.

[27] Knight, P., \& Yorke, M. (2004). Learning, curriculum and employability in Higher Education.

[28] Koh, M. Y., \& Koh, H. C. (1999). the determinants of performance in an accountancy degree programme. Accounting Education, 8(1), 13-29.

[29] Lam, T., \& Ching, L. (2006). An exploratory study of an internship program: The case of Hong Kong students. Hospitality Management, 26, 336-351.

[30] Lane, A., \& Porch, M. (2002). The impact of background factors on the performance of nonspecialist undergraduate students on accounting modules - a longitudinal study: a research note. Accounting Education, 11(1), 109-118.

[31] Lipe, M. G. (1989). Further evidence on the performance of female versus male accounting students. Issues in Accounting Education, 4(1), 144-152.

[32] Little, B., \& Harvey, L. (206). Learning through work Internships and beyond: Sheffield Hallam University and Centre for Higher Education Research and Information.

[33] Mandilaras, A. (2004). Industrial Internship and degree performance: evidence from a British higher institution. International Review of Education Economics, 3(1), 39-51.

[34] Morrison, J., Merrick, B., Higgs, S., \& Le Metais, J. (2005). Researching the performance of international students in the SL. Studies in Higher Education, 30(3), 327-337.

[35] Rawlings, P., White, P., \& Stephens, R. (2005). Practice-based learning in information systems: the advantages for students. Journal of Information Systems Education, 16(4), 455-464. 
[36] Reddy, P., \& Moores, E. (2006). Measuring the benefits of a psychology Internship year, Assessment \& Evaluation in Higher Education. 31(5), 551-567.

[37] Schambach, T., \& Dirks, J. (2002). Student perceptions of internship experiences., Proceedings of the 17 th annual conference of the international academy for information management(pp.1-8). Statesboro, GA: Georgia Southern University.

[38] Swift, C. O., \& Russell, K. (1999). Business school internships: Legal concerns. Journal of Education for Business, 75, 23-26.
[39] Weible, R. (2010). Are universities reaping the available benefits internship programs offer? Journal of Education for Business 85(2), 59-63.

[40] Woodfield, R., Jessop, D., \& McMillan, L. (2006). Gender differences in undergraduate attendance rates. Studies in Higher Education, 31(1), 1-22.

[41] Wooten, T. C. (1998). Factors influencing student learning in introductory accounting classes: a comparison of traditional and nontraditional students. Issues in Accounting Education, 13(2), 357-373. 